\title{
EVALUATION OF CHEMICAL CONTENT IN DIFFERENT ENERGY CROPS
}

\begin{abstract}
Aleksandrs ADAMOVICS, Faculty of Agriculture, Latvia University of Agriculture, Jelgava, 2 Liela Str., Latvia, aleksandrs.adamovics@1lu.lv (corresponding author) Liena POIŠA, Faculty of Agriculture, Latvia University of Agriculture, Jelgava, 2 Liela Str., Latvia, lienapoisa@inbox.lv

For energy crops (reed canary grass and timothy grass), it is important to evaluate the sulphur and carbon content, and the harvested dry matter dependency on the fertilizer norm. Sulphur and carbon are important elements of a combustible material, and carbon is directly important as it forms the burning component. On the other hand, sulphur is an unwelcome element in combustible materials as it promotes environmental pollution. The field trials were carried out in sod calcareous soils in 2011-2013. A research was conducted to investigate the chemical content of two grasses: reed canary grass var. 'Bamse' (Phalaris arundinacea L.), and timothy grass 'Jumis' (Phleum pratense L.). Fertiliser norms $\left(\mathrm{kg} \mathrm{ha}^{-1}\right)$ applied in the research were: N0P0K0 (control), N30, N60, and N90. The harvest yield is one of the most important factors to obtain biocombustible materials; however, it does not mean that the amount of the harvest yield guarantees also a good quality of grasses. The research showed that the trial year had the most significant influence on both the sulphur yield and content in dry matter, the fertiliser norm essentially influenced the sulphur $(\eta=30.1 \%)$ and carbon $(\eta=6.5 \%)$ yield, but for the sulphur yield, a $6 \%$ interaction effect was established between the trial year and the nitrogen fertilizer norm.
\end{abstract}

Keywords: energy crops, fertilizer norms, carbon content, sulphur content.

\section{INTRODUCTION}

The chemical content is an important indicator, as the ash melting temperature is dependent on it (Bumane et. al., 2017). Any form of a hard biomass combustible material is basically formed from complex organic-origin compounds that consist of five chemical elements: carbon $(\mathrm{C})$, hydrogen $(\mathrm{H})$, sulphur $(\mathrm{S})$, oxygen $(\mathrm{O})$, and nitrogen $(\mathrm{N})(\mathrm{Cars}, 2008)$. The content of non-burning elements influences the production costs for heating, as these costs are incurred for transportation. If a combustible material contains more non-burning elements, the costs of a thermal unit increase. Therefore, for the material that is moist and with a large ash content, long-distance transportation is not advantageous. In Latvia, for this type of combustible materials, fire-wood and peat can be considered (Cars, 2008).

The nitrogen fertilizer is an important indicator to evaluate the factors that influence, for instance, the harvest yield (Rancane, Karklins, 2017; Adamovics et. al., 2015; Rancane et. al., 2015). Still, many investigations have shown that by increasing the nitrogen fertilizer, many quality indicators do not change (hemicellulose, ash content, lignin) (Adamovis et. al., 2016; Rancane et. al., 2015), or also an essential influence of nitrogen fertilizer has been established (Adamovics et. al., 2017; Poisa et. al., 2017).

The objectives of this study were to examine the effect of $\mathrm{S}$ and $\mathrm{C}$ content and harvest yield in the dry matter of reed canary grass and timothy grass depending on the fertilizer norm.

\section{RESEARCH METHODS}

The field trials were carried out in the Research and Study farm "Peterlauki" $\left(56^{\circ} 53^{\prime} \mathrm{N}, 2^{\circ} 71^{\prime} \mathrm{E}\right)$ of the Latvia University of Agriculture (LLU) in 2011-2013. The soil was sod calcareous $\left(\mathrm{pH}_{\mathrm{KCl}} 6.7\right.$, containing available $\mathrm{P} 52 \mathrm{mg}$ $\mathrm{kg}^{-1}$ and $\mathrm{K} 128 \mathrm{mg} \mathrm{kg}^{-1}$; organic matter content $-21-25 \mathrm{~g} \mathrm{~kg}^{-1}$ ). The research was conducted on two grasses: reed canary grass var. 'Bamse' (Phalaris arundinacea L.) and timothy grass 'Jumis' (Phleum pratense L.). Fertiliser norms (kg ha $\left.{ }^{-1}\right)$ used in the research: $\mathrm{N}_{0} \mathrm{P}_{0} \mathrm{~K}_{0}$ (control), $\mathrm{N}_{30}, \mathrm{~N}_{60}$, and $\mathrm{N}_{90}$. Seed sowing norm: 1000 germinating seeds per $\mathrm{m}^{2}$. The firstcut herbage dry matter yield was analysed in the Analytical Laboratory for Agronomy Research (LLU) for carbon content (ISO 625, ISO 333) and sulphur content (ISO 334). The harvest yield for dry matter was established by drying a sample at $105^{\circ} \mathrm{C}$ until the mass was unchangeable (ISO 6496). The obtained results were calculated for a hectare ( $\mathrm{t} \mathrm{ha}{ }^{-1}$ ).

From each fertilizer variant, three repeat samples of the green mass of reed canary grass and timothy grass were taken and weighed exactly $\pm 0.01 \mathrm{~kg}$. The samples were used to establish the dry matter content.

Establishing the hydrothermic value (HTC) for timothy grass and reed canary grass, it can be seen that on average in the growing season, it was from 1.0 to 2.00, but the period of April, June, July, and October of 2013 was insufficiently damp. 
Excessively damp were June and July of 2011 and 2012, and August of 2011-2013. The increased dampness positively influenced the growth of reed canary grass and timothy grass, as herbaceous plants typically absorb large amounts of moisture.

The results were statistically processed using descriptive and variance statistics and dispersion analysis methods with Microsoft Excel for Windows (Arhipova, Bāliņa, 2006).

\section{RESEARCH RESULTS}

Sulphur is an important element in the formation of plant proteins, amino acids, and some vitamins and ferments. In the same way, sulphur is involved in the photosynthesis process, joint energy metabolism, and carbohydrate production. The plants choose sulphates, which are found in mineral fertilizers, as also the sulphur dioxide is found in the atmosphere.

Still, many information sources reveal that in energy crops, the sulphur content preferably should be as small as possible (Komlajeva, Adamovičs..., 2012; Kakitis, Ancans.., 2014; Poisa, Bumane.., 2017), i. e., $0.1 \%$ (Alakangas, 2010). An increased sulphur content in a combustible material produces sulphur dioxide emissions into the atmosphere.

The study found that increasing the fertilizer rate from N0 to N90 increases both the dry matter yield and the sulphur and carbon yield.

The sulphur yield of one hectare of reed canary grass (Phalaris arundinacea L.) was $282.87 \mathrm{~kg} \mathrm{ha}^{-1}$ (N0) in 2012, and $596.22 \mathrm{~kg} \mathrm{ha}^{-1}$ (N0) in 2013; but that of timothy (Phleum pratense L.) was $141.27 \mathrm{~kg} \mathrm{ha}^{-1}$ (N0) in 2012, and 600.80 $\mathrm{kg} \mathrm{ha}^{-1}$ (N0) in 2013. So large difference in the sulphur yield from one hectare is due to the different meteorological conditions in the years 2012 and 2013.

The research demonstrated that the increase in fertilizer norm does not essentially influence the sulphur content in the reed canary grass and timothy grass dry matter norms; therefore, the increase was evaluated for the influence of nitrogen fertilizer norm on the sulphur yield for one ha. For timothy grass and reed canary grass in both years of cultivation (2012-2013), the increase in fertilizer norm from N0 to N90 increased the sulphur yield by more than 100\%. On the other hand, the sulphur yield increase from one $\mathrm{kg}$ of nitrogen decreased by $75 \%$ (from N30 to N90).

It was established that sulphur content in one kg dry matter was: for timothy $-0.04 \%$ in 2012 and $0.16 \%$ in 2013 ; for reed canary grass $-0.07 \%$ in 2012 and $0.16 \%$ in 2013 ; on average $-0.10 \%$, not depending on the fertilizer norm used.

Carbon is the main burning element in a combustible material, with a high level of thermal energy (Cars, 2008). Carbon dioxide and water are formed in the process of burning carbohydrates; the energy from the sun is freed, which is a natural, sustainable battery for the accumulation of the energy of the sun. The carbon content obtained in one kg dry matter of timothy grass was 48\% in 2012 and 43\% in 2013, and that of reed canary grass was $47 \%$ in 2012 and $43 \%$ in 2013 ; on average $-45 \%$.

The carbon yield of one hectare of reed canary grass (Phalaris arundinacea L.) was $1800.57 \mathrm{~kg} \mathrm{ha}^{-1}$ (N0) in 2012 and $1937.39 \mathrm{~kg} \mathrm{ha}^{-1}$ (N0) in 2013, and that of timothy grass (Phleum pratense L.) was $1535.42 \mathrm{~kg} \mathrm{ha}^{-1}$ (N0) in 2012 and $1742.34 \mathrm{~kg} \mathrm{ha}^{-1}$ (N0) in 2013 (Tables 1 and 2).

Table 1. Carbon yield from one hectare of reed canary grass and timothy at the Research farm "Pēterlauki" in 2012

\begin{tabular}{|c|c|c|c|c|c|c|}
\hline \multirow{2}{*}{$\begin{array}{l}\text { Fertilizer } \\
\text { norm N, } \\
\mathrm{kg} \mathrm{ha}^{-1}\end{array}$} & \multirow{2}{*}{$\begin{array}{l}\text { Dry matter yield, } \\
\qquad \mathrm{t} \mathrm{ha}^{-1}\end{array}$} & \multicolumn{3}{|c|}{ Carbon yield } & \multirow{2}{*}{$\begin{array}{l}\text { Carbon yield } \\
\text { from } 1 \mathrm{~kg} \mathrm{~N}\end{array}$} & \multirow{2}{*}{$\begin{array}{c}\text { Carbon yield } \\
\text { increase from } \\
1 \mathrm{~kg} \mathrm{~N} \\
\mathrm{~kg} \mathrm{ha}^{-1}\end{array}$} \\
\hline & & $\mathrm{kg} \mathrm{ha}^{-1}$ & $\pm \mathrm{kg} \mathrm{ha}^{-1}$ & $\%$ & & \\
\hline \multicolumn{7}{|c|}{ reed canary grass (Phalaris arundinacea L.) } \\
\hline No & 3.80 & 1800.57 & - & 100 & - & 3.80 \\
\hline N30 & 6.21 & 2933.72 & 1133.15 & 163 & 97.79 & 6.21 \\
\hline N60 & 6.27 & 2980.6 & 1180.03 & 166 & 49.68 & 6.27 \\
\hline N90 & 8.39 & 4006.88 & 2206.31 & 223 & 44.52 & 8.39 \\
\hline \multicolumn{7}{|c|}{ timothy (Phleum pratense L.) } \\
\hline No & 3.15 & 1535.42 & - & 100 & - & 3.15 \\
\hline N30 & 6.48 & 3154.63 & 1619.2 & 205 & 105.15 & 6.48 \\
\hline N60 & 7.84 & 3767.08 & 2231.66 & 245 & 62.78 & 7.84 \\
\hline N90 & 8.04 & 3898.91 & 2363.49 & 254 & 43.32 & 8.04 \\
\hline
\end{tabular}

The carbon yield from one $\mathrm{kg}$ nitrogen decreased by nearly $50 \%$ if the nitrogen fertilizer norm was increased from N0 to N90 (Tables 1 and 2). Carbon yield increase from one $\mathrm{kg} \mathrm{N}$ decreased by increasing the nitrogen fertilizer norms. Such a large difference in the carbon yield from one hectare is due to the different meteorological conditions in the years 2012-2013.

The harvest yield stability indicators for some cultivated plants have been little researched, as two similar years are not possible in the countryside (Kroǵere, Pelēce, 2004). However, in the scientific literature, no specific optimal values for reed canary grass and timothy grass for the countryside conditions in Latvia have been found. It can be noted that climatic changes, specifically increased rainfall and high temperatures, will show ever larger losses (ADAS, 2005).

The trial year as a totality of agrometeorological factors had the greatest influence on the sulphur yield and content in the dry matter (Table 3). Also Finnish scientists K. Hakala, M. Kontturi un K. Pahkala (2009) have found that the harvest yield potential is influenced by the local climatic conditions. The fertilizer norm (factor C) essentially influenced 
the sulphur $(\eta=30.1 \%)$ and carbon $(\eta=6.5 \%)$ yield. For the sulphur yield, a $6 \%$ interaction between the trial year and the nitrogen fertilizer norm was established, which confirms that nutrient accessibility depends on soil fertility, fertilizer resources, and agrometeorological conditions (Hiltunen, Barišić..., 2008).

Table 2. Carbon yield from one hectare of reed canary grass and timothy at the Research farm "Pēterlauki" in 2013

\begin{tabular}{|c|c|c|c|c|c|c|}
\hline \multirow{2}{*}{$\begin{array}{l}\text { Fertilizer } \\
\text { norm N, } \\
\mathrm{kg} \mathrm{ha}^{-1}\end{array}$} & \multirow{2}{*}{ Dry matter yield, $\mathrm{t} \mathrm{ha}^{-1}$} & \multicolumn{3}{|c|}{ Carbon yield } & \multirow{2}{*}{$\begin{array}{l}\text { Carbon yield } \\
\text { from } 1 \mathrm{~kg} \mathrm{~N}\end{array}$} & \multirow{2}{*}{$\begin{array}{c}\text { Carbon yield } \\
\text { increase from } \\
1 \mathrm{~kg} \mathrm{~N} \\
\mathrm{~kg} \mathrm{ha}^{-1}\end{array}$} \\
\hline & & $\mathrm{kg} \mathrm{ha}^{-1}$ & $\pm \mathrm{kg} \mathrm{ha}^{-1}$ & $\%$ & & \\
\hline \multicolumn{7}{|c|}{ reed canary grass (Phalaris arundinacea $\mathrm{L}$.) } \\
\hline No & 4.55 & 1937.39 & - & 100 & - & - \\
\hline N30 & 5.66 & 2421.08 & 483.69 & 125 & 80.7 & 16.12 \\
\hline N60 & 7.20 & 3060.74 & 1123.35 & 158 & 51.01 & 18.72 \\
\hline N90 & 8.77 & 3743.04 & 1805.65 & 193 & 41.59 & 20.06 \\
\hline \multicolumn{7}{|c|}{ timothy (Phleum pratense L.) } \\
\hline No & 4.09 & 1742.34 & - & 100 & - & - \\
\hline N30 & 5.68 & 2426.22 & 683.88 & 139 & 80.87 & 22.8 \\
\hline N60 & 5.66 & 2414.83 & 672.49 & 139 & 40.25 & 11.21 \\
\hline N90 & 8.95 & 3782.78 & 2040.44 & 217 & 42.03 & 22.67 \\
\hline
\end{tabular}

Table 3. Proportional influence of various factors on the sulphur (S) and carbon (C) content and yield, $\eta, \%$

\begin{tabular}{lcccc}
\hline \multicolumn{1}{c}{ Factors } & $\mathrm{S}, \mathrm{kg} \mathrm{ha}^{-1}$ & $\mathrm{~S}, \%$ & $\mathrm{C}, \mathrm{kg} \mathrm{ha}^{-1}$ & $\mathrm{C}, \%$ \\
\hline Repeats & 0 & 0 & 0 & 0 \\
Trial year (A) & $41.3^{*}$ & $14.6^{*}$ & 0.2 & 0.3 \\
Species (B) & 0.5 & $66.9^{*}$ & $82.6^{*}$ & $99.3^{*}$ \\
$\mathrm{~N}$ fertilizer norm (C) & $30.1^{*}$ & $\mathrm{~ns}$ & $6.5^{*}$ & $\mathrm{~ns}$ \\
Interaction (A $\times \mathrm{B}$ ) & $11.9^{*}$ & $16.8^{*}$ & 0.2 & 0.3 \\
Interaction (A $\times$ C) & $6.0^{*}$ & 0.3 & 0.3 & $\mathrm{~ns}$ \\
Interaction (B $\times \mathrm{C}$ ) & 3.0 & 0.5 & $6.6^{*}$ & $\mathrm{~ns}$ \\
Interaction (A $\times$ B $\times \mathrm{C}$ ) & $3.8^{*}$ & 0.5 & 1.0 & $\mathrm{~ns}$ \\
Effect of unexplored factors & 3.4 & 0.1 & 2.6 & 0 \\
Total & 100 & 100 & 100 & 100 \\
\hline
\end{tabular}

* significant at the 0.05 level $\left(\mathrm{F}_{\text {fakc }}>\mathrm{F}_{0.05}\right)$

ns - not significant $\left(\mathrm{F}_{\text {fakc }}<\mathrm{F}_{0.05}\right)$

The fertiliser utilisation effectiveness depends on the specific growth circumstances in a particular year. Inclusive of the rainfall amount and temperature (Fig. 1), the most effective are the dry years (Kasal, Ruzek ..., 2011). With a higher fertiliser norm, the nitrogen fertiliser utilisation coefficient reduces. This creates a risk that the unused nitrogen compounds can pollute the environment or with rainfall enter the reservoirs (Lyons, 1998; Štikāns, 1996; Evans,1997; Scholz, Kern ..., 2010; Skrabule, Vaivode, Ruža, 2012); therefore, special attention should be paid how to use them on plants that grow in damp conditions.

An increased nitrogen fertiliser norm for the harvest yield can decrease the energy indicators, for instance, for potatoes as regards starch content (Vucāns, 1996). Therefore, the question becomes urgent about the economic effectiveness of fertilizers, which is determined by the cost of the mineral fertilizers and the purchase cost of the harvest.

This is important because cultivated plants with the highest yield have the lowest prime costs. However, it should not be forgotten that record yields may not be economically profitable in certain circumstances and require optimalisation in specific conditions (Štikāns, 1996; Wrobel, Coulman, Smith, 2009; Scholz, Kern..., 2010).

\section{CONCLUSIONS}

Ecological and agrotechnical factors influenced the yield of reed canary grass (Phalaris arundinacea L.) and timothy grass (Phleum pratense L.), which is one of the most important factors characterizing the quality of energy crops.

The increase in fertilizer rate did not significantly affect the sulphur content in the dry matter of reed canary grass (Phalaris arundinacea L.) and timothy grass (Phleum pratense L.).

The increase in fertilizer rates from N0 to N90 significantly affected the amount of sulphur and carbon yield per one hectare of reed canary grass (Phalaris arundinacea L.) and timothy grass (Phleum pratense L.).

\section{REFERENCES}

1. Adamovics, A., Platace, R., Sivicka, I. 2015. Influence of Nitrogen Fertilizer on Perennial Grass Dry Matter Yield and Suitability for Heat Production. Proceedings of the 25th NJF Congress Nordic View to Sustainable Rural Development 2015, pp. 165-169, Riga NJF, Latvia. 
2. Adamovičs, A., Platače, R., Gulbe, I., Ivanovs, S. 2017. Influence of Fertilizers on Chemical Content of Energy Grass Biomass. Proceedings of the International Scientific Conference Engineering for rural development, pp. 98-102, Latvia University of Agriculture.

3. Adamovičs, A., Platače, R., Ivanovs, S. 2016. Influence of Nitrogen Fertilizers on Chemical Composition of Energy Grass. Proceedings of the International Scientific Conference Engineering for rural development, pp. 1085-1089, Latvia University of Agriculture.

4. ADAS, 2005. UK Flax and Hemp production: The impact of changes in support measures on the competitiveness and future potential of UK fibre production and industrial use. ADAS Centre for Sustainable Crop Management report for DEFRA. Available at http://archive.defra.gov.uk/foodfarm/growing/crops/industrial/pdf/flaxhemp-report.pdf (Accessed on 12/09/2012).

5. Alakangas, E., 2010. European Standard (EN 14961) for Wood Chips and Hog Fuel. Book of proceedings Forest Bioenergy 2010, 31st August - 3rd September 2010, 47, 329-340. FINBIO Publications.

6. Arhipova, I., Bāliṇa, S., 2006. Statistika ekonomikā. Datorzinību centrs, Rīga.

7. Būmane, S., Poiša, L., Adamovičs, A., Platače, R., Čubars, E., 2017. Melting temperature behavior of different energy crop ashes. Proceedings of the International Scientific and Practical Conference Environment. Technology. Resources, Vol. 1, pp. 51-53, Rezekne Academy of Tehnologies.

8. Cars, A., 2008. Energoresursi. SIA Baltic Communication Partners, Rīga.

9. Čirkovs, J., 1978. Lauksaimniecības meteorologijas pamati. Zvaigzne. Rīga.

10. Evans, L. T., 1997. Adapting and improving crops: the endless task. Philosophical Transactions of the Royal Society Lond. B., Vol. 352, pp. 901-906. https://doi.org/10.1098/rstb.1997.0069

11. Hakala, K., Kontturi, M., Pahkala, K., 2009. Field biomass as global energy source. Agricultural and Food Science, Vol. 18 , No. 3-4, pp. 347-365.

12. Hiltunen, M., Barišić, V., Coda Zabetta, E., 2008. Combustion of Different Types of Biomass in CFB Boilers. Proceedings of the 16th European Biomass Conference \& Exhibition. June 2-6, 2008, Valencia, Spain. Available at http://fwci.com//tech papers/files/TP CFB 08 05.pdf (Accessed on 03/12/2011).

13. Kakitis, A., Ancans, D., Nulle, I., 2014. Evaluation of Combustion Properties Of Biomass Mixtures. Proceedings of the International Scientific Conference Engineering for rural development, Vol. 13, pp. 423-427, Latvia University of Agriculture.

14. Kasal, P., Ruzek, P., Kusa, H., Cepl, J., 2011. Effective ways of mineral nitrogen fertilizer applications and their effect on nitrogen use by potatoes, yield and potato quality. Ed. Santala, J., Valkonen, J.P.T. Abstracts of the 18th Triennial Conference of the European Association for Potato Research, 151, Oulu, Finland.

15. Komlajeva, L,., Adamovičs, A., Poiša, L., 2012. Comparison of Different Energy Crops for Solid Fuel Production in Latvia. Proceedings of the International Scientific Conference Renewable Energy and Energy Efficiency, pp. 45-50, Latvia University of Agriculture.

16. Krog̣ere R., Pelēce I., 2004. Augsekas produktivitāte stacionārā izmēǵinājumā saistībā ar meteorolog̣iskajiem apstākḷiem. Agronomijas Vēstis, 6, 87.-93. [In Latvian]

17. Lyons, K. E., 1998. Element Stewardship Abstract for Phalaris arundinacea L. Reed canarygrass. Eds: John M. Randall, Mona Robison, TunyaLee Morisawa, Barry at http://www.imapinvasives.org/GIST/ESA/esapages/documnts/phalaru.pdf (Accessed on 09/09/2012).

18. Poisa, L., Bumane, S., Cubars, E., Platace, R., 2017. Evaluation of Sulphur Content in Different Energy Crops. Proceedings of the International Scientific Conference Engineering for rural development, Vol. 16, pp. 1075-1079, Latvia University of Agriculture. https://doi.org/10.22616/ERDev2017.16.N227

19. Rancane, S., Karklins, A., Berzins, P., 2015. Biomass yield and chemical composition of perennial grasses for energy production. Proceedings of the International Scientific Conference Engineering for rural development, Vol. 14, pp. 546-551, Latvia University of Agriculture.

20. Rancane, S., Karklins, A., Berzins, P., Bardule, A., Butlers, A., Lazdins, A., 2017. Biomass yield and chemical composition of Phalaris arundinacea L. using different rates of fermentation residue as fertiliser. Agronomy Research, Vol. 15 (1), pp. 521-529.

21. Scholz, V., Kern, J., Kaulfuß, P., 2010. Environmental effects of energy crop cultivation - results of a long-term field trial. Agronomy Research, Vol. 8 (Special Issue II), pp. 445-452.

22. Skrabule, I., Vaivode, A., Ruža, A., 2012. Slāpekḷa mēslojuma normu ietekme uz barības vielu izmantošanās rādītājiem kartupel̦iem. Proceedings of the International Practical Conference Zinātne Latvijas Lauksaimniecības Nākotnei: Pārtika, Lopbarība, Šķiedra un Enerğija, pp. 90.-94.

23. Štikāns. J.,1996. Kalı̧ku un minerālmēslu saimnieciskā efektivitāte graudaugu sējumos. Latvijas Lauksaimniecības universitātes raksti, Nr. 3 (280), pp. 19-24. [In Latvian]

24. Vucāns, R.,1996. Minerālmēslu lietošanas efektivitāte kartupel̦u stādījumos. Latvijas Lauksaimniecības universitātes raksti, Nr. 3 (280), pp. 14-18. [In Latvian]

25. Wrobel, C., Coulman, B. E., Smith, D. L. 2009. The potential use of reedcanarygrass (Phalaris arundinacea L.) as a biofuel crop. Acta Agriculturae Scandinavica, Vol. 59, pp. 1-18. 